\title{
Reduction in the antigenicity of whey proteins by heat treatment: a possible strategy for producing a hypoallergenic infant milk formula
}

\author{
BY L. M. J. HEPPELL, A. J. CANT AND P. J. KILSHAW \\ National Institute for Research in Dairying, Shinfield, Reading RG2 9AT, Berkshire
}

(Received 18 May 1983 - Accepted 19 July 1983)

\begin{abstract}
1. Residual antigenic protein in heat-denatured cow's milk whey and in two commercial infant milk formulas was determined using enzyme-linked immunosorbent assays specific for $\beta$-lactoglobulin, $\alpha$-lactalbumin, bovine serum albumin, bovine $\operatorname{IgG}_{1}$ and $\alpha$-casein. This immunochemical assessment of antigenicity was related to the capacity of the preparations to sensitize immunologically when fed to guinea-pigs for 2 weeks. Antibody production was measured and the susceptibility of the animals to systemic anaphylaxis was assessed by injecting them intravenously with heated or unheated milk proteins.

2. Whey protein that had been heated at $100^{\circ}$ or $115^{\circ}$ for $30 \mathrm{~min}$ was extensively denatured and, in contrast to pasteurized whey, failed to sensitize guinea-pigs for anaphylaxis. Antibody production was undetected or very low. The proteins in SMA powder and SMA Gold Cap liquid concentrate were less denatured and animals given these formulas prepared according to the maker's instructions produced relatively high levels of antibodies to $\beta$-lactoglobulin and $\alpha$-casein and a majority developed anaphylaxis when injected intravenously with these products.

3. As well as failing to sensitize, whey that had received severe heat treatment did not, in most cases, elicit anaphylaxis when injected into animals that had been sensitized with unheated milk.

4. Discrimination between antibodies of the $\operatorname{IgG}_{1}$ and $\operatorname{IgG}_{2}$ subclasses specific for $\beta$-lactoglobulin showed that $\mathrm{IgG}_{1}$, the principal anaphylactic antibody in guinea-pigs, was preferentially depressed in animals drinking heat-denatured milk preparations.

5. The results suggest that heat denaturation of whey protein may be a logical and simple strategy for producing a hypoallergenic baby milk. Nevertheless, the value of experiments in guinea-pigs for predicting results in man is uncertain and the proposal awaits assessment in clinical trials.
\end{abstract}

In recent years the percentage of mothers who breast feed has increased, but artificial formulas based on cow's milk protein are still widely used. It is becoming clear that early introduction of cow's milk protein into the infant's diet can lead to allergic disease but the proportion of infants involved is controversial (Bahna \& Heiner, 1980). Alternative formulas have been developed for babies with proven or suspected cow's milk allergy. They are based mainly on soya-bean protein isolates or enzyme-hydrolysed casein. Neither approach is entirely satisfactory since preparations containing hydrolysed casein are complex to manufacture and soya-bean formulas can themselves cause immunological hypersensitivity (Ament \& Rubin, 1972; Halpin et al. 1977; Perkiö et al. 1981). Indeed, soya-bean protein may be no less antigenic than cow's milk protein (Eastham et al. 1978).

The effect of heat treatment on the antigenicity of cow's milk proteins has been investigated since early this century (reviewed by Hanson \& Johansson, 1970). In the 1950s Ratner et al. $(1958 a, b)$ showed that the antigenicity of whey proteins was reduced by heating but that casein was more heat stable. Recently, McLaughlan et al. (1981 a) observed that commercial baby milk formulas that had received severe heat treatment during manufacture sensitized guinea-pigs by mouth less efficiently than mildly heated preparations.

Previous work from this laboratory (Kilshaw et al. 1982) established that severe heat treatment of skimmed milk had little effect on its ability to sensitize guinea-pigs for systemic anaphylaxis when administered orally, but similar heat treatment applied to diafiltered whey completely abolished its sensitizing capacity. We proposed that it may be possible to produce a hypoallergenic baby milk based on heat-denatured whey and that such a 
preparation may be valuable for babies with genetic susceptibility to allergy and perhaps for those with proven cow's milk protein intolerance. The present study confirms and extends our previous results and compares the sensitizing capacity of heated whey with that of two conventional cow's-milk-based infant formulas.

\section{MATERIALS AND METHODS}

Preparation of skimmed milk and whey and the method of heat treatment has been described previously (Kilshaw et al. 1982). Whey was pasteurized by heating at $62^{\circ}$ for $30 \mathrm{~min}$ and was given at a protein concentration of $8 \cdot 1 \mathrm{~g} / \mathrm{l}$.

\section{Infant milk formulas}

SMA powder and SMA Gold Cap liquid concentrate (Wyeth, Maidenhead) were prepared as recommended for infant feeding and had a protein concentration of $15 \mathrm{~g} / \mathrm{l}$.

\section{Animals}

Male Dunkin Hartley guinea-pigs (Greystone Guinea-Pigs, Ringwood) were used for feeding experiments when they were 4 weeks old. Animals were maintained on batches of FDI diet (Labsure, Poole, Dorset) that had been shown to be milk-free by immunological testing.

\section{Feeding experiments}

Groups of four to six guinea-pigs were given heated or unheated skimmed milk or whey or infant milk formulas to drink for 2 weeks (each animal consumed about $100 \mathrm{ml} / \mathrm{d}$ ). The milk was then replaced by water and $6 \mathrm{~d}$ later blood samples were taken by cardiac puncture. The next day the animals were tested for systemic anaphylaxis by intravenous injection of $0.5 \mathrm{ml}$ of skimmed milk, heated or unheated whey, or infant milk formulas.

\section{Antibody measurements}

Serum antibodies ( $\operatorname{IgG}, \operatorname{IgG}_{1}$ and $\operatorname{IgG}_{2}$ ) to individual milk proteins were determined by an enzyme-linked immunosorbant assay (ELISA) (Heppell \& Kilshaw, 1982). All assays were standardized with pooled hyperimmune serum. $\beta$-Lactoglobulin and $\alpha$-casein were obtained from Sigma Chemical Co. (Poole, Dorset), bovine serum albumin and bovine $\mathrm{IgG}_{1}$ from Miles Laboratories (Slough, Bucks) and the other milk proteins from colleagues.

Determination of residual antigenic protein in heated whey and infant milk formulas Residual undenatured $\beta$-lactoglobulin, $\alpha$-lactalbumin, $\alpha_{\mathrm{S}_{1}}$-casein, bovine serum albumin and bovine $\mathrm{IgG}_{1}$ in heated samples and infant milk formulas were measured by a competitive inhibition ELISA (Kilshaw et al. 1982). Briefly, serial doubling dilutions of test samples were incubated with a standard dilution of antiserum and residual unbound antibodies were quantitated by ELISA. Control experiments showed that the antisera were all antigen-specific in the assay and that high concentrations of denatured protein in the test samples did not cause non-specific inhibition. Test samples were assayed in parallel with unheated skimmed milk and the number of doubling dilutions separating the mid-points of their respective assay curves was determined (Fig. 1). The level of residual antigenic protein in the test samples was expressed as a proportion, to the nearest doubling dilution, of the level in unheated milk. The assay curves for heated and unheated milk proteins differed slightly in shape (Fig. 1); this may reflect a reduction in the affinity for antibody in partially denatured or heat-aggregated molecules. 


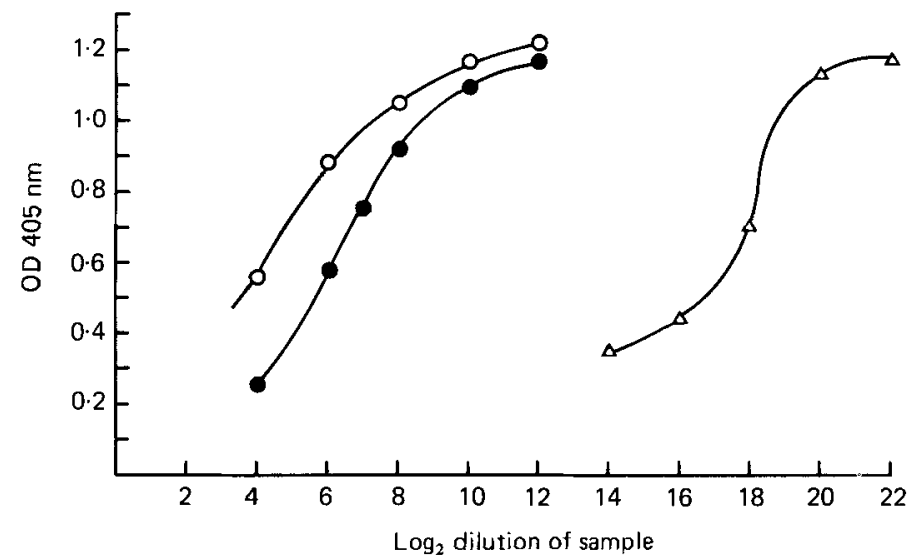

Fig. 1. Assay of $\beta$-lactoglobulin in test samples of whey heated at $100^{\circ}$ for $30 \mathrm{~min}(\mathrm{O})$ or $115^{\circ}$ for $30 \mathrm{~min}$ $(O)$, showing respectively, $1 / 2048$ and $1 / 8192$ of the level of undenatured $\beta$-lactoglobulin in unheated skimmed milk $(\triangle)$.

\section{RESULTS}

Immunoassay of residual antigenic protein in heated whey and infant milk formulas Results are shown in Table 1. Heat treatment of diafiltered whey resulted in extensive denaturation of all the whey proteins, while the small amount of $\alpha_{\mathrm{S1} 1}$-casein present was little affected. Comparison between the two commercial formulas showed that SMA Gold Cap liquid concentrate contained lower levels of antigenic $\alpha$-lactalbumin, bovine serum albumin and bovine $\mathrm{IgG}_{1}$, and higher levels of $\beta$-lactoglobulin and $\alpha_{\mathrm{S1}}$-casein than SMA powder. However, the differences between the two formulas were small and the levels of all the residual antigenic proteins were higher than in heated whey.

Table 1. Residual antigenic proteins in heated whey and in infant milk formulas (proportion of values for unheated skimmed milk)

\begin{tabular}{|c|c|c|c|c|c|}
\hline & $\begin{array}{l}\beta \text {-Lacto } \\
\text { globulin }\end{array}$ & $\begin{array}{l}\alpha \text {-Lactal- } \\
\text { bumin }\end{array}$ & $\alpha_{\mathrm{sl}}$-Casein & $\begin{array}{l}\text { Bovine serum } \\
\text { albumin }\end{array}$ & Bovine $I_{g G_{1}}$ \\
\hline $\begin{array}{l}\text { Pasteurized } \\
\text { diafiltered whey }\end{array}$ & $1(1 / 2)^{*}$ & 1 & $1 / 256$ & 1 & $1(1 / 2)^{*}$ \\
\hline $\begin{array}{l}\text { Diafiltered whey } \\
\text { heated } 100^{\circ} \text { for } 30 \mathrm{~min}\end{array}$ & $1 / 2048$ & $1 / 32$ & $1 / 512$ & $<1 / 64 \dagger$ & None detected \\
\hline $\begin{array}{l}\text { Diafiltered whey } \\
\text { heated } 115^{\circ} \text { for } 30 \mathrm{~min}\end{array}$ & $1 / 8192 \dagger$ & $1 / 512$ & $1 / 512$ & $<1 / 64 \dagger$ & None detected \\
\hline $\begin{array}{l}\text { SMA powder } \\
\text { (reconstituted to } \\
15 \mathrm{~g} \text { protein } / \mathrm{l} \text { ) }\end{array}$ & $1 / 64(1 / 128)^{*}$ & $1 / 4$ & $1 / 4(1 / 8)^{*}$ & $1 / 2(1 / 4)^{*}$ & $1 / 256$ \\
\hline $\begin{array}{l}\text { SMA Gold Cap liquid } \\
\text { concentrate (reconstituted to } \\
15 \mathrm{~g} \text { protein } / \mathrm{l})\end{array}$ & $1 / 32(1 / 64)^{*}$ & $1 / 8$ & 1 & $1 / 16(1 / 32)^{*}$ & $<1 / 1024 \dagger$ \\
\hline
\end{tabular}

* Where results of duplicate experiments differed, these are shown in parentheses.

$\uparrow$ Less than $1 \mu \mathrm{g}$ undenatured protein $/ \mathrm{ml}$. 
Table 2. Anaphylaxis in guinea-pigs drinking unheated or heated milk and whey or infant milk formulas

\begin{tabular}{|c|c|c|c|c|}
\hline Group & Milk fed & Heat treatment & $\begin{array}{l}\text { Intravenous challenge } \\
\qquad(0.5 \mathrm{ml})\end{array}$ & $\begin{array}{c}\text { Anaphylaxis } \\
\text { (number fatal) }\end{array}$ \\
\hline 1 & Diafiltered whey & $\begin{array}{cc}\text { Pasteurization } \\
100^{\circ} & 30 \mathrm{~min} \\
100^{\circ} & 30 \mathrm{~min} \\
115^{\circ} & 30 \mathrm{~min}\end{array}$ & $\begin{array}{l}\text { Preparation fed } \\
\text { Preparation fed } \\
\text { Pasteurized whey } \\
\text { Skimmed milk }\end{array}$ & $\begin{array}{l}4 / 4(4) \\
0 / 10 \\
0 / 4 \\
0 / 5\end{array}$ \\
\hline 2 & Skimmed milk & $\begin{array}{l}\text { None } \\
\text { None } \\
\text { None } \\
\text { None }\end{array}$ & 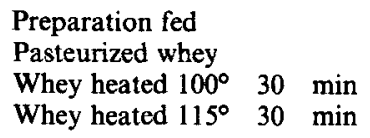 & $\begin{array}{l}5 / 5(5) \\
3 / 3(3) \\
3 / 6(1) \\
1 / 6(0)\end{array}$ \\
\hline 3 & SMA powder & Spray dried* & Preparation fed & $4 / 5(3)$ \\
\hline 4 & $\begin{array}{l}\text { SMA Gold } \\
\text { Cap liquid } \\
\text { concentrate }\end{array}$ & $\begin{array}{c}\text { Concentrated } \\
\text { and } \\
\text { sterilized } \dagger\end{array}$ & Preparation fed & $3 / 5(2)$ \\
\hline
\end{tabular}

Heating data for SMA powder and SMA liquid concentrate obtained from Wyeth Laboratories, Maidenhead. Also see McLaughlan et al. $(1981$ a).

- $105^{\circ}$ for $30 \mathrm{~s}$ and cooled. Preheated to $78^{\circ}$ then put into spray drier and heated to $167^{\circ}$ (drying occurs instantaneously).

$\dagger$ Whey concentrated in falling film evaporator, $72^{\circ}$ for $15 \mathrm{~s}$. Electrodialysed at $37^{\circ}$. Other ingredients added. Heated to $77^{\circ}$ for $16 \mathrm{~s}$ then $122^{\circ}$ for $5.6 \mathrm{~min}$.

Anaphylaxis in guinea-pigs drinking unheated or heated milk and whey or baby milk formulas for 2 weeks (Table 2)

All guinea-pigs drinking unheated skimmed milk or pasteurized whey became sensitized so that when these milks were injected intravenously the animals died of anaphylaxis. Additional heat treatment of pasteurized whey abolished its anaphylactic sensitizing capacity (Table 2, group 1). This confirms our previous results (Kilshaw et al. 1982). Heat treatment of whey considerably reduced its capacity to elicit anaphylaxis in guinea-pigs sensitized by feeding with unheated milk (Table 2, group 2). Anaphylactic reactions occurred in three out of six animals injected with steamed whey and one out of six injected with autoclaved whey. Only one reaction was fatal. SMA powder and SMA Gold Cap liquid concentrate sensitized the majority of guinea-pigs for anaphylaxis (Table 2, groups 3 and 4). Slightly fewer animals reacted against SMA liquid concentrate than SMA powder.

\section{Antibody production in guinea-pigs drinking unheated or heated milk and whey or baby} milk formulas for 2 weeks (Table 3)

Serum antibodies to whey proteins and $\alpha$-casein were detected in all animals drinking unheated milk or pasteurized whey. In contrast, guinea-pigs receiving steamed or autoclaved whey failed to produce circulating antibodies to $\alpha$-lactalbumin, bovine $\mathrm{IgG}_{1}$ and bovine serum albumin. Low titres of antibodies to $\beta$-lactoglobulin and $\alpha$-casein were detected in some animals.

The levels of serum antibodies to $\alpha$-lactalbumin, bovine $\mathrm{IgG}_{1}$ and bovine serum albumin in guinea-pigs given either of the baby milk formulas were very low, while anti- $\beta$-lactoglobulin titres were high and similar to those in animals drinking unheated whey. Guinea-pigs drinking either of the formulas produced antibodies to $\alpha$-casein but titres were higher in the group receiving SMA powder. 


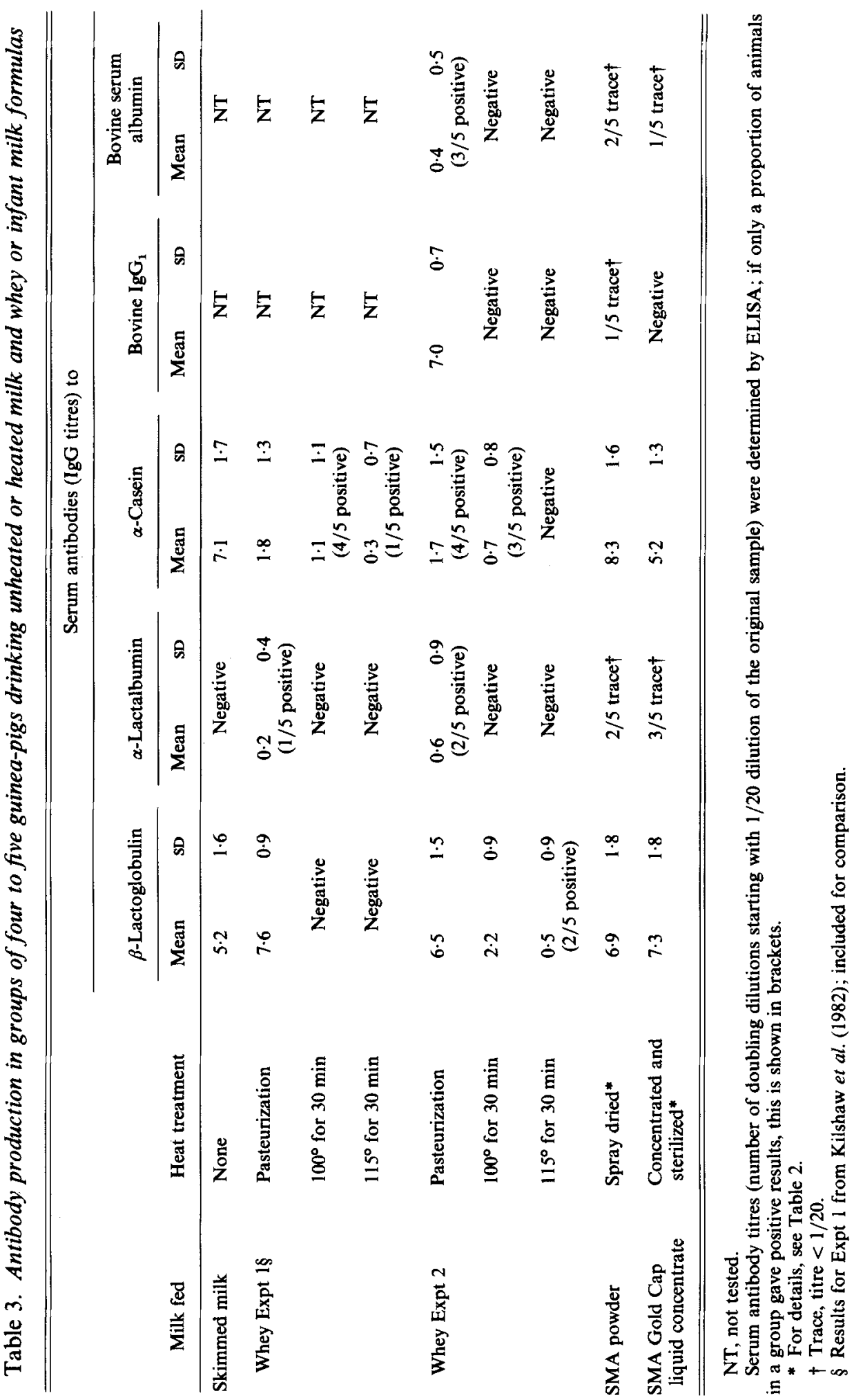




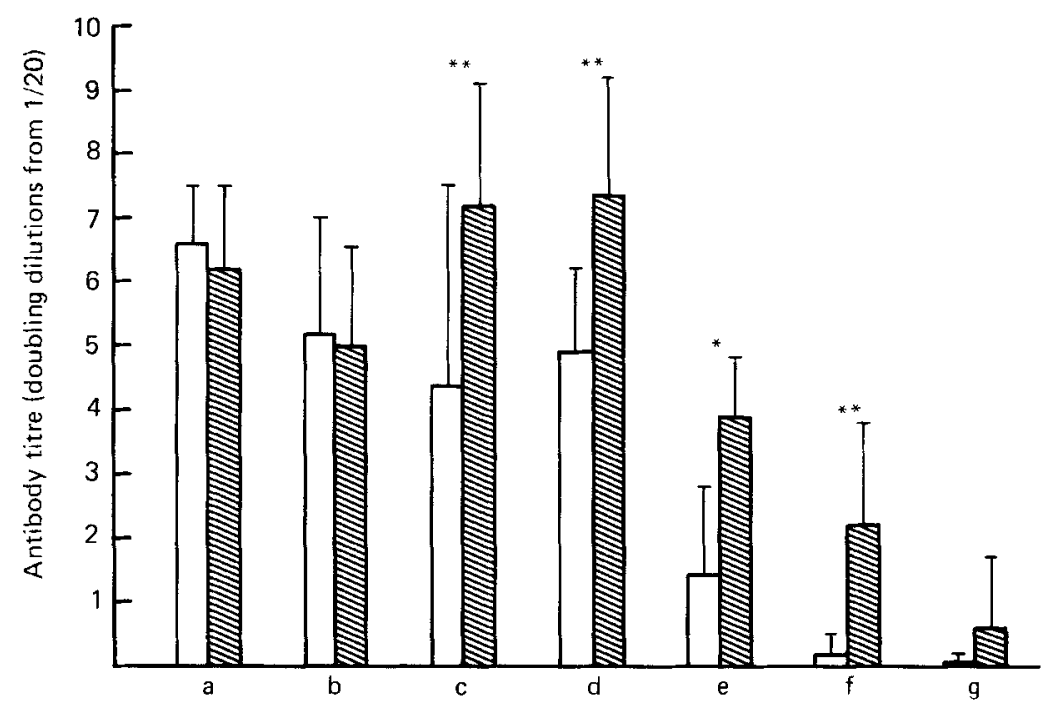

Fig. 2. $\operatorname{IgG}_{1}(\square)$ and $\operatorname{IgG}_{2}$ ( antibody production in guinea-pigs drinking (a) pasteurized whey, (b) unheated milk, (c) SMA powder, (d) SMA Gold Cap liquid concentrate, (e) heated milk $121^{\circ}$ for 20 min, (f) heated whey $100^{\circ}$ for $30 \mathrm{~min}$, (g) heated whey $115^{\circ}$ for $30 \mathrm{~min}$. Significant difference between $\mathrm{IgG}_{1}$ and $\mathrm{IgG}_{2}$ levels (Student's $t$ test): ${ }^{*} P=0.02-0.05,{ }^{* *} P=0.01-0.001$.

\section{Subclass of IgG antibody to $\beta$-lactoglobulin in guinea-pigs drinking unheated or heated} milk and whey or baby milk formulas

Fig. 2 demonstrates that $\beta$-lactoglobulin antibodies of the $\mathrm{IgG}_{1}$ subclass were preferentially depressed in all guinea-pigs drinking heated milk or whey. Although antibody titres were high in animals given SMA powder and SMA liquid concentrate, a similar preferential depression of the $\operatorname{IgG}_{1}$ subclass was still observed.

\section{DISCUSSION}

The advantages of breast milk for most babies are well known, but artificial feeds must be available as supplements or alternatives. A reduction in immunological sensitizing capacity of cow's milk protein in infant feeds would be desirable, especially for babies with genetic susceptibility to atopic disease.

The value of feeding trials in guinea-pigs to predict the allergenicity of foods for man is uncertain. The pathogenesis of food allergy in man is poorly understood but shares with our guinea-pig experiments the special feature of immunological sensitization by the oral route. Guinea-pigs respond readily to oral presentation of antigen by becoming sensitized for anaphylaxis and producing high levels of antibodies. Their response may be a sensitive indicator of the antigenicity of food protein during digestion and absorption, but should not be interpreted to indicate the threshold dose of antigen for sensitization in man nor, therefore, the precise extent of heat denaturation appropriate for infant milk formulas.

Parallels between results in guinea-pigs and man have been drawn by other workers. Manuel \& Walker-Smith (1981) observed that the speed of recovery of infants suffering from acute gastroenteritis, known to be especially susceptible to cow's milk protein intolerance, was affected by their milk formula. Pregestimil (based on hydrolysed casein) and SMA Gold Cap powder were beneficial, while AL110 (which contains purified casein) delayed recovery. They interpreted these results to reflect differences in the immunological sensitizing capacity 
of the three formulas. Experiments in guinea-pigs showed that AL110 was the most immunogenic of the three, Pregestimil failed to sensitize, SMA Gold Cap powder was intermediate but caused fatal anaphylaxis in $75 \%$ of the animals (McLaughlan et al. $1981 a, b)$.

In the present study, guinea-pigs responded to unheated whey by producing antibodies mostly to $\beta$-lactoglobulin and bovine $\operatorname{IgG}_{1}$. Heat treatment of whey denatured the proteins to an extent where they failed to sensitize for anaphylaxis and evoked little or no antibody production. Very low levels of serum antibodies to $\beta$-lactoglobulin and $\alpha$-casein were detected in some animals. The reduction in antigenicity in vivo was accompanied by a corresponding decrease in antibody binding capacity in vitro and it is likely that the residual antigenic whey protein measured by ELISA reflected the antigenic stimulus in vivo. Not only did heat treatment abolish the anaphylactic sensitizing capacity of whey, but also it considerably reduced the ability of whey proteins to elicit anaphylaxis in animals sensitized by drinking unheated milk.

The proteins in SMA powder and SMA Gold Cap liquid concentrate were less denatured than in heated whey and were correspondingly more immunogenic in vivo. There was little difference in the sensitizing capacity of the two formulas although SMA liquid concentrate sensitized fewer guinea-pigs for systemic anaphylaxis than SMA powder, agreeing with the results of McLaughlan et al. (1981 a). The two formulas differ from each other in the extent of heating applied during manufacture and in the ratio of whey:casein. SMA liquid concentrate is more severely heated and has a higher whey : casein value than SMA powder $(60: 40$ compared with $20: 80$ in SMA powder). The opposing considerations of concentration and heat denaturation determine the relative levels of antigenic whey protein in the two formulas. For casein, which cannot easily be denatured by heat, greater heat treatment in SMA Gold Cap liquid concentrate increased antibody binding capacity in the ELISA. This anomaly may be due to changes in micellular structure during severe heat treatment of the SMA liquid concentrate which result in increased accessibility of antigenic determinants to antibody. Despite these results, SMA Gold Cap liquid concentrate evoked lower levels of antibodies to casein than SMA powder. A similar discrepancy between immunochemical and in vivo determination of antigenicity has been reported for casein in heated and unheated skimmed milk (Kilshaw et al. 1982). Possibly, casein in severely heated preparations is more rapidly degraded during digestion and absorption and therefore constitutes a weaker antigenic stimulus to the guinea-pigs.

The observation that $\mathrm{IgG}_{1}$ antibodies to $\beta$-lactoglobulin were preferentially depressed in guinea-pigs given heated milk products suggests that production of this subclass, which is considered to be the principal anaphylactic antibody in guinea-pigs, was more susceptible to a reduction in antigen dose than $\mathrm{IgG}_{2}$. A similar dose relationship for parenterally administered antigen in adjuvant has been reported by Nakamura \& Koyama (1975). Thus, systemic anaphylaxis may not be the most sensitive indicator of immunological sensitization in guinea-pigs.

Our results suggest that heat treatment of whey protein may be a simple and logical strategy for producing a hypoallergenic baby milk. The proposal can be truly validated only by clinical trials. To avoid the formation of undesirable Maillard reaction products during heat treatment it would be desirable first to reduce the lactose concentration by diafiltration. Carbohydrates, vitamins and minerals could be added back later.

We thank Mr F. A. Glover for preparing the diafiltered whey, Dr R. L. J. Lyster for the gift of antisera and purified whey proteins, and the staff of the animal house for their assistance throughout this work. Dr A. J. Cant is the holder of an ARC/MRC Training Fellowship in Human Nutrition. 


\section{REFERENCES}

Ament, M. E. \& Rubin, C. E. (1972). Gastroenterology 62, 227-234.

Bahna, S. L. \& Heiner, D. C. (1980). Allergies to Milk, pp. 5-9. New York: Grune \& Stratton.

Eastham, E. J., Lichauco, T., Grady, M. I. \& Allan Walker, W. (1978). Journal of Pediatrics 93, 561-564.

Halpin, T. C., Byrne, W. J. \& Ament, M. E. (1977). Journal of Pediatrics 91, 404-407.

Hanson, L. Å. \& Johansson, B. G. (1970). In Milk Proteins: Chemistry and Molecular Biology, vol. I, pp. 96-101 [H. A. McKenzie, editor]. New York and London: Academic Press.

Heppell, L. M. J. \& Kilshaw, P. J. (1982). International Archives of Allergy and Applied Immunology 68, 54-59.

Kilshaw, P. J., Heppell, L. M. J. \& Ford, J. E. (1982). Archives of Disease in Childhood 57, 842-847.

Mclaughlan, P., Anderson, K. J., Widdowson, E. M. \& Coombs, R. R. A. (1981 a). Archives of Disease in Childhood 56, 165-171.

McLaughlan, P., Anderson, K. J. \& Coombs, R. R. A. (1981 b). Clinical Allergy 11, 311-318.

Manuel, P. D. \& Walker-Smith, J. A. (1981). Acta Paediatrica Belgica 34, 13-20.

Nakamura, T. \& Koyama, J. (1975). Immunochemistry 12, 931-934.

Perkkiö, M., Savilahti, E. \& Kuitunen, P. (1981). European Journal of Pediatrics 137, 63-69.

Ratner, B., Dworetzky, M., Oguri, S. \& Aschheim, L. (1958a). Pediatrics 22, 648-652.

Ratner, B., Dworetzky, M., Oguri, S. \& Aschheim, L. (1958b). Pediatrics 22, 653-658. 